Resenhas 



\title{
OS LAÇOS FEITOS ENTRE A LINGUAGEM E A SUBJETIVIDADE
}

Por Leonardo Pinto de Almeida $\star$

GORLIER, J. C. Nudos del lengaje: cuerpo, escritura, voz. Mar del Plata: EUDEM, 2011.

\section{Resumo}

Esta resenha apresenta o livro Nudos del lengaje: cuerpo, escritura, voz , de Juan Carlos Gorlier. Este livro tece uma compreensão consistente das relações entre linguagem, literatura, subjetividade e corpo.

Palavras-chave: linguagem; literatura; subjetividade.

\section{The BOWS MADE BeTWEen THE LANGUAGE AND THE SUBJECTIVITY}

\begin{abstract}
This review presents the book Nudos del lengaje: cuerpo, escritura, voz, by Juan Carlos Gorlier. This book shows a consistent understanding of the relations between language, literature, subjectivity and body

Keywords: language; literature; subjectivity.

São poucos os mágicos que após o espetáculo apresentam aos espectadores a resolução da ilusão produzida. Aqueles que o fazem, quando com maestria, deixam mesmo uma sensação de mistério ainda perpassando nossas cabeças.

A escrita de Nudos del lengaje atravessa os destinos da linguagem com a magia e maestria assinaladas. Juan Carlos Gorlier, após cada um dos capítulos que produzem um misto de escrita literária e filosófica com a leveza do pensamento focado, mostra, aos leitores desavisados, os traços e os rastros filosóficos que o inspiraram detidamente.

Nudos del lengaje não é uma obra habitual. Daí o seu encanto. Comumente somos atravessados por uma escrita filosófica dura que muitas vezes esquece que o pensamento deve funcionar em todo lugar e não somente na academia... Esse livro traz potência ao pensamento, além de sua graciosidade estética.

\footnotetext{
^Psicólogo. Doutor em Psicologia pela Pontifícia Universidade Católica do Rio de Janeiro com estágio de doutorado sanduíche no Centre de Recherche sur la Lecture Littéraire da Universidade de Reims Champagne-Ardenne. Realizou Pós-doutorado em Psicologia pela Pontifícia Universidade Católica do Rio de Janeiro. Atualmente, é Professor Adjunto da Universidade Federal Fluminense e Editor da Revista ECOS - Estudos Contemporâneos da Subjetividade.

E-mail:1eonardo.p.almeida@gmail.com
} 
Uma resenha é uma espécie singela de homenagem ao autor, mas sobretudo à prática de leitura, pois tenta deixar viva ainda os traços que ocuparam a produção de sentido e a prática do pensamento. Ler essa obra foi agradável e inquietante, porque a experiência leitora em questão é uma das consequências diretas do encontro virtual entre dois pesquisadores que têm nas experiências filosófica e literária seu foco e sua verdadeira paixão. Juan e eu nos encontramos através da linguagem escrita trocada a certa distância. É interessante como linguagem e leitura, uma de suas práticas, produzem efeitos contundentes nas subjetividades que atravessam. De certo modo, esse é um dos problemas analisados em Nudos del lengaje. Quais são as vicissitudes da linguagem? Quais são as relações traçadas entre a linguagem, o corpo, o poder, a escritura?

Essas são questões que atravessam todo o livro. Como a função de uma resenha é contagiar o outro com a inspiração de ler a obra. Algo deveras simples e ao mesmo tempo difícil. Já que o contágio muitas vezes não segue a lógica da importância, da novidade e da utilidade, mas da paixão pelo pensamento e pela leitura. Daí a própria função da resenha se encontra como paradoxal. Como contaminar o leitor pela vontade de ler o livro sem utilizar a esfera da necessidade?

No entanto, uma resenha se coloca como um ensaio... misto de paixão e relevo dos traços de uma relação amorosa com a coisa escrita. Assim, trataremos aqui do impacto que esse livro me causou...

Como assinalado antes, esse livro segue uma forma de escrita pouco habitual. Juan Carlos Gorlier traça verdadeiras reflexões sobre os destinos da linguagem, acompanhado de perto por alguns ilustres parceiros de pensamento, como Foucault, Deleuze, Guattari, Nancy, Lyotard, Badiou, Barthes, Blanchot, Merleau-Ponty e Derrida. Esses eminentes pensadores franceses do século XX trazem à escritura inspiração para pequenas pérolas reflexivas que podem se chamar de capítulos ou sessões. O livro se compõe de 22 delas.

Cada uma trata de um problema inspirado por um desses pensadores. Os nomes desses fazem pares com o título de cada sessão. A escrita inquietante, que mescla o filosófico e o literário sem cair na dureza já assinalada, produz traços reflexivos sem tentar cair nas ilhotas de definição e de conclusão, tão comuns à esfera interpretacional. $\mathrm{O}$ texto usa citações filosóficas não da forma habitual - como para reforçar um argumento ou esclarecê-lo - , elas são colocadas para se confundir ou se fundir com o andamento da reflexão imposta pela escritura, fazendo do filósofo escolhido, um verdadeiro parceiro de questionamento. Daí, a ideia dos títulos fazerem pares com os nomes dos filósofos que o inspiraram.

Essas sessões trazem à baila reflexões sobre os nós, os laços, da linguagem que tornam a escritura, corpo. Assim, os capítulos perpassam questões, como a escuta, a marionete, a escritura fragmentária, o devir-criança, as vozes inarticuladas, o livro como máquina infernal, o corpo insignificante, o gaguejar, a obra como texto, o rememorar, a força, a carne, o grão da voz, o corpo sem órgãos, a alma mínima, a voz narrativa, os detalhes, o acontecimento, o olhar, o corpo como sítio do acontecimento, a atenção, e a estridência. 
O mais interessante é que, a cada texto escrito, o autor nos brinda com notas bibliográficas e biográficas do pensador que o inspirou a refletir sobre o problema levantado. É como se o mágico tentasse nos explicar a ilusão produzida, mesmo sabendo que o mistério da magia nunca se perde.

Como se pode observar, essas questões são tomadas em verdadeiras parcerias filosóficas, pois usam conceitos e reflexões como estopim de uma análise límpida sobre os destinos da linguagem. A questão sobre qual seria a relação entre a linguagem e a produção do corpo, da subjetividade, é o mote desse belo livro.

E mais ainda, o que motiva o livro são questões verdadeiramente filosóficas, que quando mescladas com uma escrita de tom literário, colocam em relevo à questão como questão, já que ela é sempre o motor dos pensamentos como tal. Assim poderíamos evocar Blanchot quando esse afirma: "Questionar é jogar-se na questão. A questão é esse convite ao salto, que não se detém num resultado." (BLANCHOT, 2001, p.53) Juan salta realmente na questão profunda da linguagem, nesse redemoinho de Maelstrom que tudo transforma. É por esse motivo, que o livro Nudos del lengaje é um bonito convite aos leitores e às leitoras a mergulharem nas profundezas da linguagem

\section{REFERÊNCIAS}

BLANCHOT, M. A conversa infinita, a palavra plural. São Paulo: Escuta, 2001. v. 1.

GORLIER, J. C. Nudos del lengaje: cuerpo, escritura, voz. Mar del Plata: EUDEM, 2011.

Recebido em: 14 de setembro de 2012

Aceito em: 10 de outubro de 2012 
